\title{
Singapore 2003
}

\author{
By Toh, Hai Leong \\ Fall 2003 Issue of KINEMA \\ SINGAPORE INTERNATIONAL FILM FESTIVAL (SIFF) 2003
}

Last year, the $15^{\text {th }}$ SIFF received a quarter million Singapore dollars from the Singapore Film Commission (SFC). This year, no money was forthcoming - yet the quality and quantity of the programming was not compromised.

In fact, critics from Malaysia, the Philippines, Hong Kong, Britain and even those from Singapore, praised the impressive programme - in particular the Asian film selection for which the SIFF is known and which has made it № 3 in Asia, after Pusan and Hong Kong. Noted British film critic Derek Malcolm wrote in The Guardian that the $16^{\text {th }}$ SIFF (17 April-3 May 2003) was "one of the strongest for some time", while Wong T. C., chairman of the Malaysian Art Film Club tagged it "one of the best in years".

But then the unforeseen happened. The 2003 SARS (Severe Acute Respiratory Syndrome) outbreak in early March looked set to doom the entire festival with its load of 350 films from 24 countries even before its fringe programme could take place in early April!

Not unexpectedly, some festival guests failed to turn up but that also saved the cash-strapped SIFF some expenses. In spite of the health scare, the festival still managed to attract sufficient audiences, especially for a few controversial films such as the homegrown 'gangster' flick 15 which was sold out. Other entries including the Singapore-Vietnam co-production Song of the Stork, Bowling For Columbine, Too Young To Die, Desire, Ho Yuk: Let's Love Hong Kong, Flying With One Wing, Pasolini's The Gospel According To Saint Matthew, his controversial Saló or 120 Days of Sodom, and a few others also drew in good crowds.

Many film buffs who knew of Im Kwon-taek's status as a master of the South Korean cinema were willing to fork out the expensive tickets (at two-and-a-half times the usual S\$8.30) for his Chihwaseon (Strokes of Fire, 2002), which was chosen as the Festival's opening gala. Played with understated grace by veteran Choi Min-shik as the $19^{\text {th }}$ century genius painter Jang Seung-up (aka Ohwon), known for his womanising and drunkenness, the film became a hit with local film buffs.

Attendance was almost 60 percent of the 1299-seat Prince 1 theatre when Elia Suleiman's quirky, dark and fantastical Divine Intervention closed the festival on 3 May. This whimsical portrayal of petty neighbourly feuds in Nazareth, where absurd little wars erupt, is blackly humorous beneath the deceptive banalities of everyday life. Among the characters are a man who dumps his rubbish in his neighbour's garden, a homosexual who waits for a bus that never comes, two elderly Arab men who watch their neighbour line up his roof-top with beer bottles, a Palestinian from Jerusalem called ES (played by the director himself) who can only meet his beloved from Ramallah in a deserted parking lot sandwiched between the two cities, doing nothing but watch the absurdities of the power-crazed Israeli guards with increasing impotent anger. But what does the title mean? It soon becomes clear when the fantastical elements come in the form of ES's fiancée who turns into a ninja-style Palestinian super-heroine, stopping an elite squad of Israeli commandos dead in their tracks. Who says an émigré Palestinian filmmaker like Suleiman (who lived in New York in self-imposed exile for a number of years) cannot comment on the great violent divide of his homeland?

This year, the festival managed to mount four major directors' retrospectives: the established Pier Paolo Pasolini and Sergei Paradjanov, as well as Sri Lanka's Dharmasena Pathiraja, who has been making films about the social and political realities of the underclass since the mid-70s, along with his talented younger compatriot, Asoka Handagama. These younger middle generation of Sri-Lankan filmmakers make a clean break from the 50s-60s romantic-bourgeois tradition pioneered by the husband-and wife team of James Lester and Sumitra Peries.

Despite the SARS scare, Dr. Peter Zimmermann, the Academic director of the Documentary Film Centre (European Media Forum, Stuttgart) arrived to discuss seven documentaries shown between 13 to 18 April at the Goethe Institut. And despite the festival's shrunken budget, the fringe's indie films on video shown at the SIFF were free and free-spirited. As the saying goes, the best things in life are free. 
This year also saw the understated but significant follow-up of Malaysia's 'new wave' which started around 2000 with remarkable films by Osman Ali (Bukak Api), Amir Muhammad (Lips to Lips), Teck Tan (Spinning Top) and James Lee (Ah Beng Returns). Three impressive made-for-TV films (Odissi series under executive producer Osman Ali) - Rabun, Min and Tetanga made their debuts here.

Rabun is a deftly directed and charming 94-min bio-pic of director Yasmin Ahmad's parents, who are openly affectionate towards each other and whose humanity transcends class, racial and cultural differences. Min, short for Yas(min), directed by Ho Yuhang (displaying his characteristic Hou-Hsiao-hsien-like long takes) portrays a Chinese woman in search of her biological mother. Tetangga, is a 56-min featurette by Desmond $\mathrm{Ng}$ with a story somewhat like Min, about a woman who travels to the city to babysit her newborn granddaughter. These movies reveal that the Malaysian filmmakers have come of age and their 'new wave' movement may gradually lift the traditionally insular Malaysian film industry to international prominence.

Complementing these outstanding but low-key digital video works were Amir Muhammad's The Big Durian, "a thorny tale" about the socio-political events in Malaysia in 1987, and James Lee's Room To Let. Lee, inspired by Pasolini's Theorem, tells of a slacker, Berg, whose presence brings about some fundamental changes in the lives of those staying with him in the house.

In contrast, Singapore's film production with several features a year for the last decade, is still waiting for its "new wave". With the exception of the promising Wee Lilin who won this year's Silver Screen Special Achievement Award For Short Films with Autograph Book, there are no new talents quirky enough to deliver something one could proudly called 'our Singaporean film.' So far only three local 'indie' features, Lim Suat Yen's The Road Less Travelled (1996), Ong Lay Jinn's Return To Pontianak (2000) and Vince Wong's Hype (2001), showed a specific Singapore cinematic sensibility. However, some films stand out, like Sandi Tan's short - the food-and-sex allegory Gourmet Baby (2002) which she funded herself, and the Vietnam war movie Song of the Stork (2002) by Jonathan Foo who co-directed it with the Vietnamese Nguyen Phan Quang Binh. Vastly superior to the over-praised Royston Tan's pretty but empty 'gangster' flick 15, Foo's melancholic Song of the Stork engaged viewers with the story of four North Vietnamese combatants who sacrificed their lives for "the greater good". Yet the NETPAC-FIPRESCI Award went to 15.

Two other strong films of the festival were Indonesian Garin Nugroho's Bird Man Tale, an allegory about Irian Jaya Papua's call for self-rule from Indonesia which lost her hold over East Timor after much bloodshed and mayhem more than a year ago. The other was Shinya Tsukamoto's claustrophobically 'noirish' sexual blackmail fable, A Snake of June. The marginally entertaining Unknown Pleasures, brought to screen four hopeless young people who drive themselves to the crossroads of ennui and despair. The film received a Special Mention which should have gone to 15. Blissfully Yours got the Young Cinema award with bouts of overly long driving and mundane talks. The closely-cropped Sri Lankan theatre actress, Anoma Janadari, truly deserved her Best Actress award. In the controversial Flying With One Wing, she plays with understated power a male transsexual mechanic who was born a woman. When her secret is discovered, all hell breaks loose in the traditionally-minded community.

The virtually unknown Taiwanese actor, Wing Fan, plays the cool gangster Wei, who gets into serious trouble with a rival gang in Chang Tso-chi's low-key, masterfully shot The Best of Times - arguably the director's best gangster film to date.

The Tajik film, Angel On The Right, is about an ex-convict who returns home to help his apparently dying mother who uses this ruse for him to repair her house and settle debuts owed to the mayor. Director Jamshed Usmonov's message seems to be: "Trust no one, not even your loved ones." Usmonov's confident handling of the material won him the Best Director prize.

Refreshingly surprising at this year's SIFF was the discovery of Palestinian and Arab films - both documentaries and fiction. Especially with Divine Intervention, and others such as James Longley's Gaza Strip (USA, 2001/02), Sherine Salama's A Wedding in Ramallah (Australia, 2002), Crossing Kalandia, Frontiers of Dreams and Fears, and Staying Alive give alternative views to the stereotyped suicide bomber image and are a reminder that the Palestinians, the Israelis and even the Americans who are backing them, are all quite human. 


\section{References}

\section{AWARDS}

Silver Screen Awards for Asian Features

Best Asian Feature Film

The Best of Times (Taiwan 2002), Chang Tso-chi

Best Director

Angel On The Right (Tajikistan 2000), Djamshed Usmonov

Best Actor

Wing Fan (The Best of Times, Taiwan 2002), Chang Tso-chi)

\section{Best Actress}

Anoma Janadari (Flying With One Wing, Sri Lanka 2002), Asoka Handagama

Young Cinema Award

Blissfully Yours (Sud Sanaeha, Thailand 2002), Apichatpong Weerasethakul

Special Jury Prize

Flying With One Wing (Sri Lanka, 2002), Asoka Handagama

Special Mention

Unknown Pleasures. (China-Japan-France 2002), Jia Zhangke

NETPAC-FIPRESCI

15 (Singapore 2002), Royston Tan

SINGAPORE SHORT FILM CATEGORY

No awards were given for Best Film, Director and Special Jury Prize

Special Achievement Award

Autograph Book (Singapore 2002), Wee Li Lin

\section{Author Information}

TOH Hai Leong is a Singapore-based freelance film critic and filmmaker (Zombie Dogs, 2005) who writes for independent film publications such as Screen International and World Paper. He has covered the Hong Kong International Film Festival since 1985 and specializes in the cinemas of Hong Kong, Taiwan, China, Korea and Japan. 